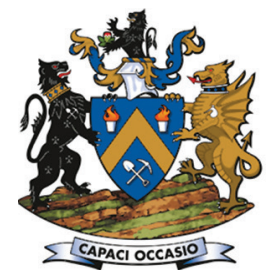

Affiliation:

1 University of Johannesburg, Mineral Processing and Technology Research Centre, Department of Metallurgy, School of Mining, Metallurgy and Chemical Engineering, Faculty of Engineering and the Built Environment, Johannesburg, South Africa.

Correspondence to: B.M. Thethwayo

Email:

77mpilot@gmail.com

Dates:

Received: 28 Nov. 2019

Revised: 2 Jun. 2020

Accepted: 3 Jun. 2020

Published: June 2020

\section{How to cite:}

Hlongwa, R.K. Thethwayo, B.M., and Mulaba-Bafubiandi, A.F.

On the interactions of iron

sulphide with alumina and silica.

The Southern African Insitute of

Mining and Metallurgy

DOI ID:

http://dx.doi.org/10.17159/24119717/1035/2020

ORCiD ID:

B.M. Thethwayo, https://orchid.org/0000-00019929-8828

A.F. Mulaba-Bafubiandi https://orchid.org/0000-00019752-3657

\title{
On the interactions of iron sulphide with alumina and silica
}

\author{
R.K. Hlongwa ${ }^{* 1}$, B.M. Thethwayo ${ }^{1}$, and A.F. Mulaba-Bafubiandi ${ }^{1}$ \\ "Paper written on project work carried out in partial fulfilment of BTech \\ (Metallurgical Engineering) degree
}

\begin{abstract}
Synopsis
The hypothesis that matte will only react with certain constituents of a refractory brick, as opposed to the entire brick, was tested by observing the extent of possible reactions between iron sulphide (FeS) and the refractory oxides silica and alumina. The main aim was to identify the components of the alumina-chrome refractory brick which are most reactive with the matte. Pellets comprised of FeS and either $\mathrm{SiO}_{2}$ or $\mathrm{Al}_{2} \mathrm{O}_{3}$ were enclosed in a graphite crucible and reacted in a horizontal tube furnace for one hour at $1200^{\circ} \mathrm{C}, 1350^{\circ} \mathrm{C}$, or $1500^{\circ} \mathrm{C}$ in an argon atmosphere. The specimens were analysed with SEM and XRD to determine the extent of any reactions. Results showed that FeS penetration into the silica grain was more prominent with increasing temperature, while alumina was not penetrated by FeS at all temperatures. At $1200^{\circ} \mathrm{C}$, no significant reactions were observed for both reaction couples; however, at $1350^{\circ} \mathrm{C}$ and $1500^{\circ} \mathrm{C}$ intermediate products were observed. For example, an FeS FeO mixture, SiS-O, and nonstoichiometric oxides with excess oxygen were detected in the products. $\mathrm{SiO}_{2}$ was also more reactive towards FeS. Thus, the postulation that brick components may individually be reactive towards matte was proved to be true.
\end{abstract}

\section{Keywords}

FeS-FeO-SiO, FeS- $\mathrm{Al}_{2} \mathrm{O}_{3}$, matte-refractory interaction, oxide-sulphide reactions.

\section{Introduction}

Refractory bricks used in lining PGM smelters can be alumina-chrome or magnesia-chrome based. In modern PGM furnace linings, graphite blocks have replaced these oxide refractories in the feed and slag zones. The use of graphite has improved the service life of the refractory lining by obstructing migration of furnace contents towards the copper coolers (Thethwayo and Garbers-Craig, 2014, Thethwayo and Cromarty, 2015). The study of the interaction between the refractory bricks and matte at different temperatures enables informed decisions in refractory innovation and increases knowledge of materials which are less likely to react with and/or dissolve into the matte.

A typical industrial PGM matte consists of $\mathrm{Cu}$-Fe-Ni-S compounds and up to $10 \%$ by weight of oxide inclusions (Thethwayo and Cromarty, 2015, Thethwayo, 2019). The structure of a typical industrial matte sample is shown in Figure 1, in which the mode of occurrence of the oxide inclusions in the matte is displayed. The matte and oxide inclusions for the current study were analysed with an electron probe micro-analyser to determine the chemical composition of the phases. The matte was composed of $(\mathrm{Fe}, \mathrm{Ni})_{9} \mathrm{~S}_{8}, \mathrm{FeS}$ and $\mathrm{Cu}_{5} \mathrm{FeS}_{4}$, and no slag elements i.e. (Al, $\mathrm{Ca}, \mathrm{Cr}, \mathrm{Mg}$, $\mathrm{Na}$, and $\mathrm{Si}$ ) were detected in the sulphide phases. The oxide inclusions were composed of ( $\mathrm{Al}, \mathrm{Ca}, \mathrm{Fe}, \mathrm{Mg}) \mathrm{Si}_{2} \mathrm{O}_{5},(\mathrm{Al}, \mathrm{Si}) \mathrm{O}_{2},(\mathrm{Ca}, \mathrm{Na}$ ) (Al, Si) ${ }_{4} \mathrm{O}_{8}$, (Fe, $\mathrm{Mg}$ ) $\mathrm{SiO}_{3}, \mathrm{Fe}_{2} \mathrm{SiO}_{4}, \mathrm{FeCr}_{2} \mathrm{O}_{4}$ (Thethwayo, 2019), $\mathrm{CaAl}_{2} \mathrm{Si}_{2} \mathrm{O}_{8}$, and $\mathrm{SiO}_{2}$ (du Toit, Cromarty, and Garbers-Craig, 2016). The oxide phases did not have elements associated with the matte, i.e. $\mathrm{Cu}$, $\mathrm{Ni}$, and S Fe can either be in the matte as a sulphide or in the slag as an oxide/silicate (Thethwayo 2019, du Toit, Cromarty, and Garbers-Craig,, 2016). Based on the composition and the occurrence of the oxides in Figure 1, the oxides appear to be inclusions in the matte, and there was no evidence of oxide dissolution in it.

The presence of oxide inclusions in the matte causes major challenges to furnace operations due to the formation of spinel phases which hinder matte-slag separation in converters. The presence of chromite increases the liquidus temperature of the slag, which necessitates elevated operating temperatures in the converting step (Eksteen, 2011; Hundermark, 2011). The high operating temperatures affect the operations and reduce the lifespan of the reaction vessels. The oxide inclusions are capable of reacting with the matte and altering its composition (Thethwayo and Cromarty, 2015). Contaminated matte also poses a challenge for the subsequent step in matte processing. 


\section{On the interactions of iron sulphide with alumina and silica}
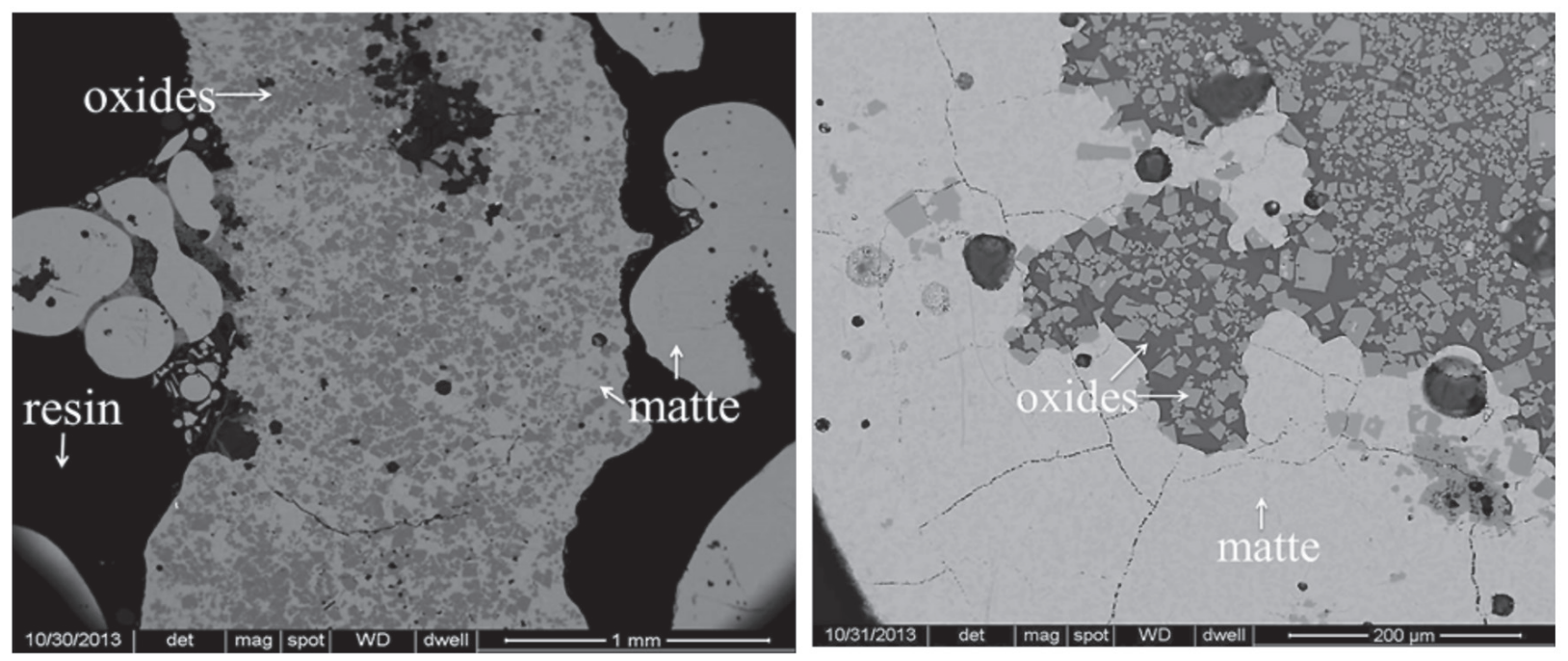

Figure 1-An SEM-BSE image illustrating the morphology of a typical industrial matte sample with oxide inclusions (Thethwayo, 2019)

The source of oxides in the matte can either be the slag or the oxide refractories (Thethwayo, 2019). A typical alumina-chrome brick consists of $75 \% \mathrm{Al}_{2} \mathrm{O}_{3}, 20.7 \% \mathrm{Cr}_{2} \mathrm{O}_{3}, 2.2 \% \mathrm{P}_{2} \mathrm{O}_{5}$, and $1 \%$ $\mathrm{SiO}_{2}$ (du Toit, Cromarty, and Garbers-Craig, 2016). On the other hand, a magnesia-chrome brick contains 58\% $\mathrm{MgO}, 19 \% \mathrm{Cr}_{2} \mathrm{O}_{3}$, $14 \% \mathrm{Fe}_{2} \mathrm{O}_{3}, 6.5 \% \mathrm{Al}_{2} \mathrm{O}_{3}, 1.1 \% \mathrm{CaO}$, and $0.6 \% \mathrm{SiO}_{2}$ (Eksteen, 2011).

Comparing the composition of the refractory brick and that of the oxide inclusions discussed above, there is a probability that the refractory brick is the source of some of the oxide inclusions in the matte. Above $1500^{\circ} \mathrm{C}$ the matte is capable of sulphurizing the magnesia-chrome brick. High temperatures and sulphidation reactions lead to the decomposition of the refractory, which is undesirable (Eksteen 2011). The destruction of the refractory brick causes furnace breakdowns, operational downtime, and loss of overall production due to maintenance and replacement of the damaged bricks.

The mechanism for oxide migration into matte has not been reported. Ramakobya, Thethwayo, and Mulaba-Bafubiandi (2019) studied the interaction of FeS with $\mathrm{Cr}_{2} \mathrm{O}_{3}$ and $\mathrm{Fe} / \mathrm{MgCr}_{2} \mathrm{O}_{4}$. $\mathrm{Fe} / \mathrm{MgCr}_{2} \mathrm{O}_{4}$ caused volume expansion of $\mathrm{FeS}$ at $1200^{\circ} \mathrm{C}$; as the temperature increased to $1450^{\circ} \mathrm{C}$, a new phase was observed (FeS Cr) with up to 8 weight \% Cr (Ramakobya, Thethwayo, and Mulaba-Bafubiandi, 2019). The formation of FeS-Cr proved that FeS has a capability to destroy the refractory brick by extracting Cr into solution.

This project aimed to study the probability of FeS dissolving some refractory components into solution at typical matte operating temperatures of $1200^{\circ} \mathrm{C}, 1350^{\circ} \mathrm{C}$, and $1500^{\circ} \mathrm{C}$. Only FeS was used to represent the matte, and only $\mathrm{Al}_{2} \mathrm{O}_{3}$ and $\mathrm{SiO}_{2}$ were tested as refractory components. This was to simplify the test work and to isolate the matte components since the entire matte has a complex composition and not all the matte components may be reactive. Similarly, two brick components were used instead of the entire brick to verify the hypothesis that PGM matte reacts chemically with certain refractory components, and not the entire brick.

\section{Materials and experimental methods}

The reactants used were iron sulphide, silica, and alumina, which were acquired from Sigma Aldrich and Associated Chemical Enterprises. The as-received powders were characterized using $\mathrm{X}$-ray fluorescence (XRF) and X-ray diffraction (XRD).

Diffraction patterns of as-received samples and generated products were acquired using a Rigaku Ultima IV instrument. The voltage and the current of the X-ray source were set to $40 \mathrm{kV}$ and $30 \mathrm{~mA}$ respectively. The instrument had a CuK $(\lambda=1.54) \mathrm{X}$-ray generator target with a maximum power of $3 \mathrm{~kW}$.

As-received powder samples were pulverized to $-75 \mu \mathrm{m}$. For XRF analysis, the sample was mixed with wax and pressed into a pellet. The generated products were characterized with scanning electron microscopy (SEM), and XRD. A camera was used to acquire images of the pellets before and after exposure.

The SEM used was a TESCAN (Vega 3XMU) equipped with a tungsten filament as an electron source and was fitted with a backscattered electron (BSE) detector and an energy dispersive $\mathrm{X}$ ray spectroscopy (EDS) detector. The BSE detector used for image acquisition employed Vega software. EDS was used to determine the chemical composition of the detected phases using INCA software from Oxford Instruments. The standard for SEM calibration was pure copper, while the beam energy used was $20 \mathrm{keV}$.

SEM was used for analysing pellets after exposure. These were cut longitudinally to prepare a cross section. Samples were cold-mounted in epoxy resin and sections were polished to the finest size of 1 MD nap. They were then coated with carbon before SEM analysis.

\section{Experimental procedure}

The as-received powder samples were milled to less than $100 \mu \mathrm{m}$ to ensure homogeneity of the sample. The ratio of the reactant mixture in each pellet was $10 \mathrm{~g}$ FeS to $2 \mathrm{~g} \mathrm{Al}_{2} \mathrm{O}_{3}$ or $\mathrm{SiO}_{2}$. This ratio was selected based on the amount of oxide inclusions in the matte. The weighed aliquot powders were pressed into a $20 \mathrm{~mm}$ diameter pellet using a press and die. The pellet was enclosed in a graphite crucible with a lid to isolate the specimen from the environment. An alumina plate was placed between the crucible and the specimen to prevent contact between the specimen and the crucible. The specimen set-up is illustrated in Figure 2. 


\section{On the interactions of iron sulphide with alumina and silica}

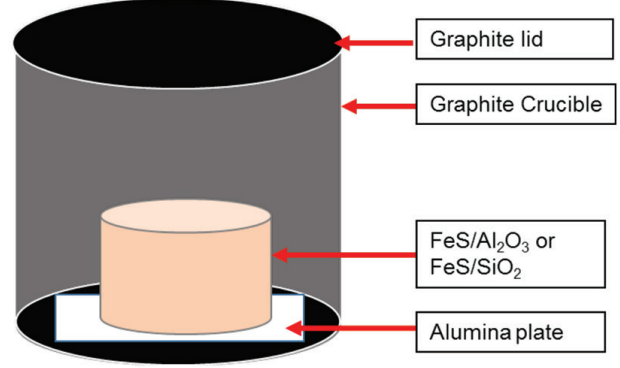

Figure 2-Experimental set-up

A horizontal tube furnace was heated with silicon carbide elements, and an alumina working tube was used for containment. The alumina tube was sealed with steel plates at both ends. In each steel plate was a gas line which served as an inlet/outlet for the purging gas. Argon was used to purge the set-up throughout the experiment to prevent the oxidation of the specimen.

Operating temperatures were $1200^{\circ} \mathrm{C}, 1350^{\circ} \mathrm{C}$, and $1500^{\circ} \mathrm{C}$, based on typical operating temperatures in PGM smelters. The holding time at a particular temperature was 1 hour; the aim of this was to study the interaction at the point of contact, because operating at longer contact times would introduce other factors such as loss of volatiles. The experiments were repeated twice at each temperature to determine the reproducibility of results. The $\mathrm{FeS} / \mathrm{Al}_{2} \mathrm{O}_{3}$ and the $\mathrm{FeS} / \mathrm{SiO}_{2}$ specimens were placed simultaneously inside the furnace to minimize variability and error in the results. After each reaction, the specimens were cooled under an argon atmosphere and were then removed from the furnace. The images of the pellet post exposure were captured by a camera for optical analysis, and are reported under the results section.

Each pellet was cut longitudinally to produce two samples; one sample was pulverized in preparation for XRD analysis, while the remaining half was mounted for SEM analysis. The XRD patterns, BSE images, and EDS analyses of the reaction products are presented in the next section. Before exposure, the reactants were analysed by SEM-EDS and XRD to determine the composition of the starting materials and the level of impurities. XRD detects only crystalline phases, but the SEM would be able to detect all the possible phases.

\section{Results}

The EDS analysis of the as-received powders is presented in Table I. The chemical phases were estimated using atomic ratios. The chemical compositions of the alumina and the silica were close to the targeted reactants, and no impurities were detected in the oxide reactants. The chemical composition of the iron sulphide matched that of $\mathrm{FeS}_{2}$. The target sulphide was $\mathrm{Fe}_{(1-\mathrm{x})} \mathrm{S}$, which is the constituent of PGM matte, and the XRDpattern of the as-received iron sulphide powder is shown in Figure 3 . As detected by the EDS, pyrite $\left(\mathrm{FeS}_{2}\right)$ was the only phase identified by XRD in the iron sulphide powder. The Fe-S phase diagram is depicted in Figure 4, with the data presented for a total pressure of 1 bar and temperatures above $400^{\circ}$. $\mathrm{CFeS}_{2}$ converts to $\mathrm{Fe}_{(1-\mathrm{x})} \mathrm{S}$ and sulphur at $743^{\circ} \mathrm{C}$ (Walder and Pelton, 2005, Tesfaye and Taskinen, 2010); at constant pressure sulphur is vaporized (Walder and Pelton, 2005). In the current work, the operating temperature was from $1200^{\circ} \mathrm{C}$ to $1500^{\circ} \mathrm{C}$; at these temperatures the $\mathrm{FeS}_{2}$ would have converted to $\mathrm{Fe}_{(1-\mathrm{x})} \mathrm{S}$ according the phase diagram. The $\mathrm{FeS}_{2}$ was used as received, and the assumption was made that $\mathrm{FeS}_{2}$ would convert to $\mathrm{Fe}_{(1-\mathrm{x})} \mathrm{S}$ before the operating temperature is reached. The effects of starting with $\mathrm{FeS}_{2}$ were assumed to be negligible.

The XRD patterns of the as-received alumina and silica powders are shown in Figure 5. The detected phases confirmed the SEM-EDS analysis in Table I. The alumina pattern depicted was that of corundum $\left(\mathrm{Al}_{2} \mathrm{O}_{3}\right) \cdot \mathrm{SiO}_{2}$ has a number of polymorphs which have different crystallinity, and the XRD pattern fitted that of cristobalite which is slightly different from that of quartz. No impurities were detected in either the alumina and the silica.

\section{Table I}

SEM-EDS analysis of as-received $\mathrm{Al}_{2} \mathrm{O}_{3}, \mathrm{FeS}$, and $\mathrm{SiO}_{2}$ powders (weight \%)

\begin{tabular}{|l|c|c|c|}
\hline Element & $\mathbf{A l}_{2} \mathbf{O}_{3}$ & $\mathbf{F e}_{(1-x)} \mathbf{S}$ & $\mathbf{S i O}_{2}$ \\
\hline $\mathrm{O}$ & 50.9 & - & 57.5 \\
$\mathrm{Al}$ & 48.5 & - & - \\
$\mathrm{Fe}$ & 0.6 & 46.4 & - \\
$\mathrm{S}$ & - & 53.6 & - \\
$\mathrm{Si}$ & - & - & 42.5 \\
\hline
\end{tabular}

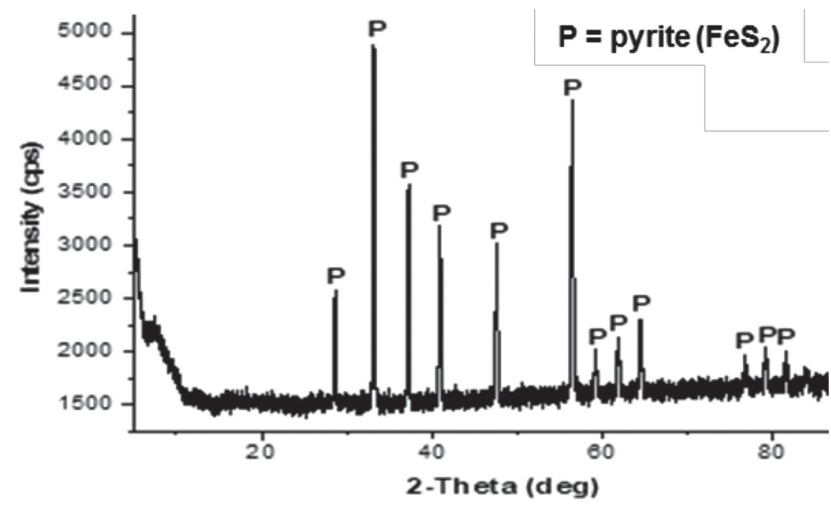

Figure 3-XRD pattern of as-received iron sulphide powder

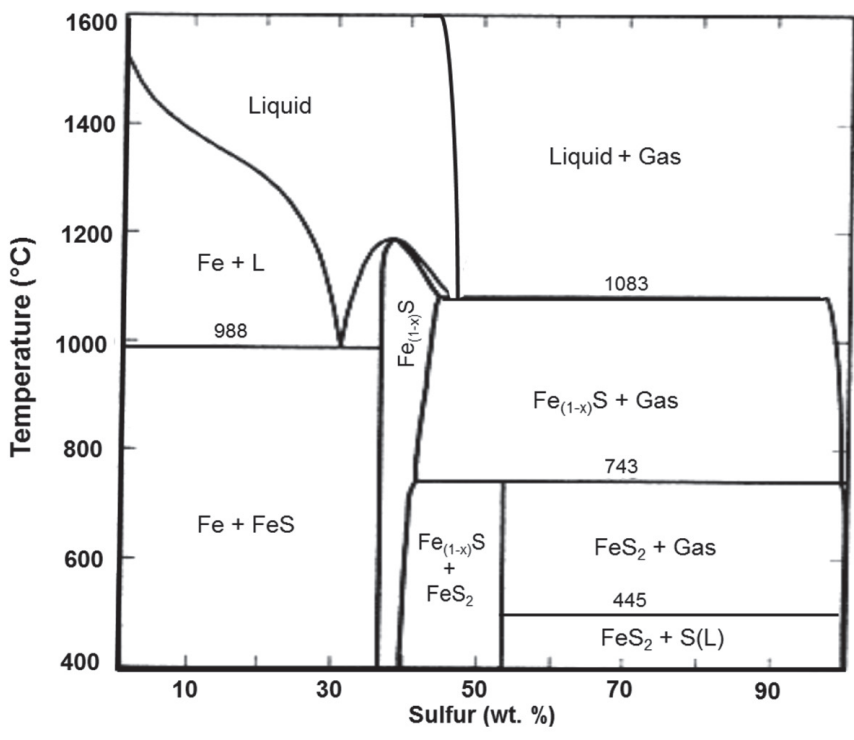

Figure 4-Calculated, optimized Fe-S phase diagram at a total pressure of 1 bar, for temperatures above $400^{\circ} \mathrm{C}$ (Walder and Pelton, 2005) 


\section{On the interactions of iron sulphide with alumina and silica}
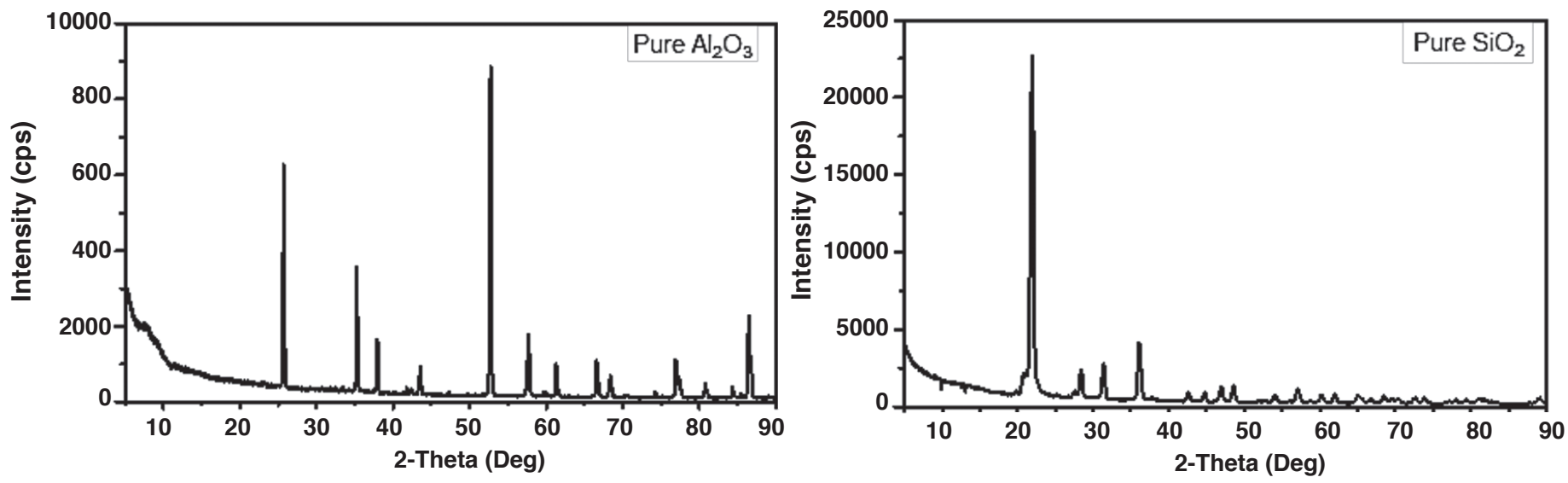

Figure 5-XRD patterns of as-received alumina and silica

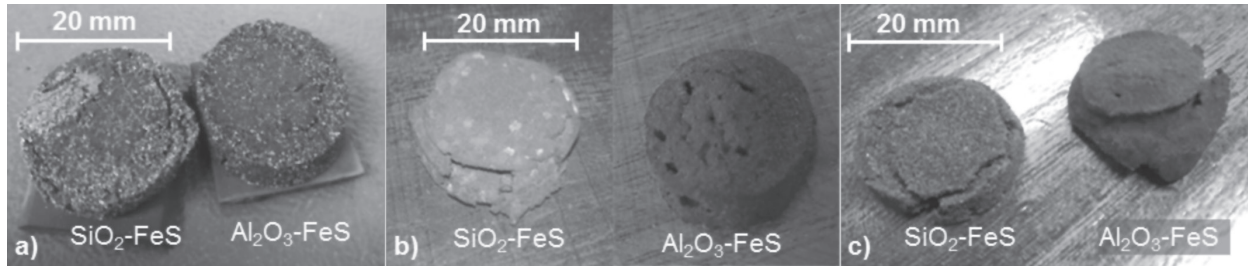

Figure 6-Images of the pellets after exposure at (a) $1200^{\circ} \mathrm{C}$, (b) $1350^{\circ} \mathrm{C}$, (c) $1500^{\circ} \mathrm{C}$
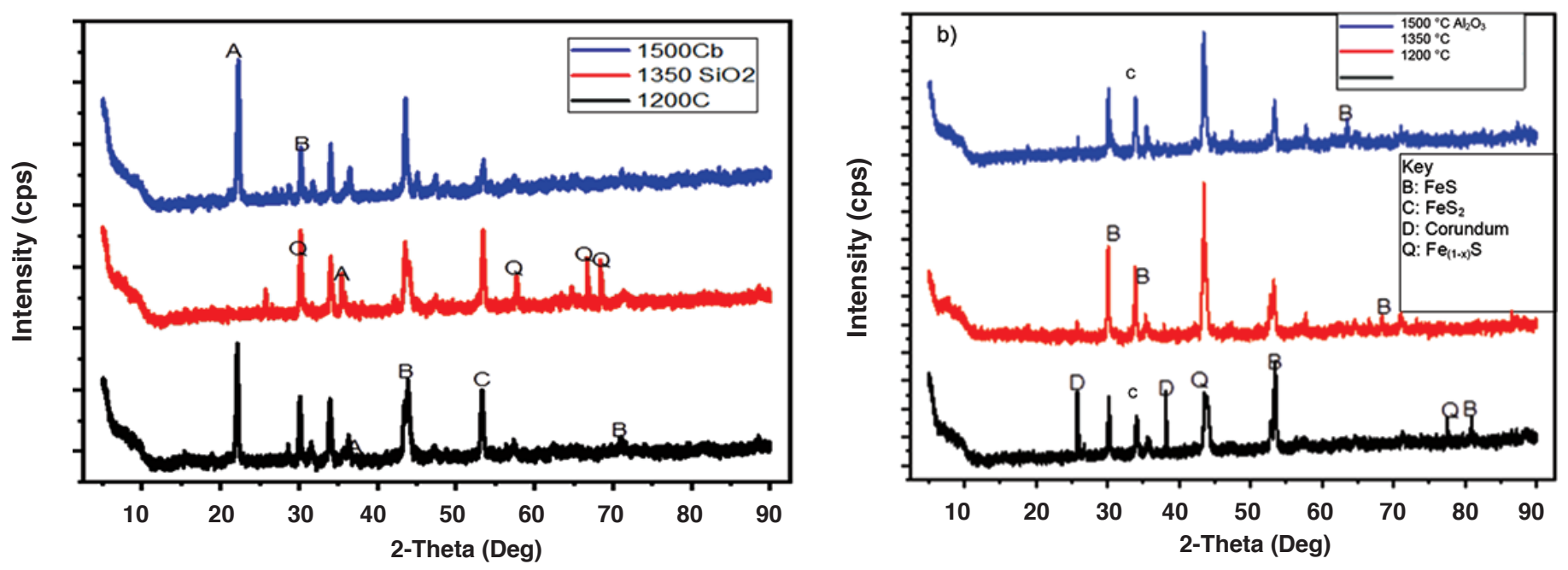

Figure 7-XRD patterns with identified peaks for (a) $\mathrm{FeS} / \mathrm{SiO}_{2}$ specimen and (b) $\mathrm{FeS} / \mathrm{Al}_{2} \mathrm{O}_{3}$ specimen

Figures $6 \mathrm{a}, 6 \mathrm{~b}$, and $6 \mathrm{c}$ are images of the specimens after exposure at $1200^{\circ} \mathrm{C}, 1350^{\circ} \mathrm{C}$, and $1500^{\circ} \mathrm{C}$ respectively. At $1200^{\circ} \mathrm{C}$ (Figure 6a), the $\mathrm{SiO}_{2}$ pellet developed minor cracks, while the $\mathrm{Al}_{2} \mathrm{O}_{3}$ pellet did not show significant changes. At $1350^{\circ} \mathrm{C}$ (Figure $6 \mathrm{~b})$, the cracks on the $\mathrm{SiO}_{2}$ pellet were more noticeable, and the colour of the pellet became light grey with whitish spots. The $\mathrm{Al}_{2} \mathrm{O}_{3}$ pellet developed pores, and a slight increase in volume was observed.

At $1500^{\circ} \mathrm{C}$ (Figure $6 \mathrm{c}$ ) the cracks on the $\mathrm{SiO}_{2}$ pellet enlarged. The diameter of the pellet increased by $0.2 \mathrm{~mm}$, the colour became darker than at $1350^{\circ} \mathrm{C}$, and the whitish spots were not

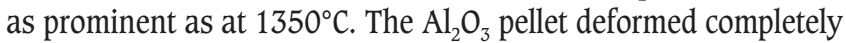
and the pores diminished after exposure at $1500^{\circ} \mathrm{C}$.

The XRD patterns of the $\mathrm{FeS} / \mathrm{SiO}_{2}$ and the $\mathrm{FeS} / \mathrm{Al}_{2} \mathrm{O}_{3}$ specimens for all temperatures are displayed in Figures $7 \mathrm{a}$ and
$7 \mathrm{~b}$ respectively. The patterns are arranged hierarchically; the bottom, middle, and top patterns are for the specimens at $1200^{\circ} \mathrm{C}$, $1350^{\circ} \mathrm{C}$, and $1500^{\circ} \mathrm{C}$ respectively. The identified phases are annotated on the graphs.

The $\mathrm{FeS} / \mathrm{SiO}_{2}$ products contained cristobalite $\left(\mathrm{SiO}_{2}\right)$ and iron sulphide phases $\left(\mathrm{FeS}, \mathrm{Fe}_{(1-\mathrm{x})} \mathrm{S}\right.$, and $\left.\mathrm{FeS}_{2}\right)$. An interesting observation was the absence of the cristobalite peak at $1350^{\circ} \mathrm{C}$; the other phases were detected at all the temperatures.

The FeS/ $\mathrm{Al}_{2} \mathrm{O}_{3}$ products contained corundum $\left(\mathrm{Al}_{2} \mathrm{O}_{3}\right)$ and iron sulphide phases ( $\mathrm{FeS}, \mathrm{Fe}_{(1-\mathrm{x})} \mathrm{S}$, and $\mathrm{FeS}_{2}$ ). The corundum peak is notably absent at $1350^{\circ} \mathrm{C}$ and $1500^{\circ} \mathrm{C}$; however, the sulphide phases were present at all temperatures.

The SEM-BSE images of the $\mathrm{FeS} / \mathrm{SiO}_{2}$ pellet are depicted in Figures $8 \mathrm{a}, 8 \mathrm{~b}$, and $8 \mathrm{c}$ for the specimens exposed at $1200^{\circ} \mathrm{C}$, $1350^{\circ} \mathrm{C}$, and $1500^{\circ} \mathrm{C}$ respectively. The SEM EDS analyses of the 


\section{On the interactions of iron sulphide with alumina and silica}

phases annotated 1 to 9 in Figure 8 are presented in Table II. At $1200^{\circ} \mathrm{C}$, two phases were identified, a nonstoichiometric $\mathrm{SiO}_{2}$ and an iron sulphide mixture $\left(\mathrm{Fe}_{(1-\mathrm{x})} \mathrm{S} / \mathrm{FeS}_{2}\right)$. New products were not detected at $1200^{\circ} \mathrm{C}$ and it seemed that the $\mathrm{SiO}_{2}$ had not melted at this temperature. However, cracks were observed in the $\mathrm{SiO}_{2}$ grains.

At $1350^{\circ} \mathrm{C}$, a new phase was observed, which is annotated 5 in Figure 8b. The chemical composition of the new phase was $\mathrm{SiO}_{4}$; this was estimated using the weight percentages reported in Table II. The $\mathrm{SiO}_{2}$ and the $\mathrm{Fe}_{(1-x)} \mathrm{S} / \mathrm{FeS}_{2}$ mixture were still present at $1350^{\circ} \mathrm{C}$; however, a slight penetration of the iron sulphide into the $\mathrm{SiO}_{2}$ grain was observed. At $1500^{\circ} \mathrm{C}$ the penetration of iron sulphide through $\mathrm{SiO}_{2}$ was more apparent, and the $\mathrm{SiO}_{2}$ also containes more pronounced cracks. The $\mathrm{SiO}_{4}$ phase that was observed at $1350^{\circ} \mathrm{C}$ was still present at $1500^{\circ} \mathrm{C}$, and is annotated 6 in Figure 8c. A minor phase, annotated 7, consisted of sulphurenriched $\mathrm{SiO}_{2}$. The FeS/FeO mixture was detected (Figure 8c, annotated number 8), while the residual silica was oxygenenriched, giving a chemical composition of $\mathrm{SiO}_{4}$ (numbered 9 in Figure 8c). The nonstoichiometry of the oxide phases cast doubt on the accuracy of the EDS analysis, but the analysis gave an indication on the extent of the reaction. The BSE images illustrated the interaction between the oxide and the sulphide, and the presence of intermediate phases was apparent.

Figure 9 depicts the $\mathrm{FeS} / \mathrm{Al}_{2} \mathrm{O}_{3} \mathrm{BSE}$ images, and the products after exposure at $1200^{\circ} \mathrm{C}, 1350^{\circ} \mathrm{C}$, and $1500^{\circ} \mathrm{C}$ are depicted in Figures $9 \mathrm{a}, 9 \mathrm{~b}$, and $9 \mathrm{c}$ respectively. The EDS analyses of the annotated phases are presented in Table III. At $1200^{\circ} \mathrm{C}$, no significant interaction was observed and the phases detected were $\mathrm{Al}_{2} \mathrm{O}_{3}$ and the $\mathrm{Fe}_{(1-\mathrm{x})} \mathrm{S} / \mathrm{FeS}_{2}$ mixture. At $1350^{\circ} \mathrm{C}$, two new phases were detected, namely a nonstoichiometric $\mathrm{Al}_{2} \mathrm{O}_{3}$ and the $\mathrm{FeS} / \mathrm{FeO}$ mixture, numbered 3 and 6 in Figure $9 \mathrm{~b}$ respectively. The $\mathrm{Al}_{2} \mathrm{O}_{3}$ contained excess oxygen, but no sulphur or iron.

At $1500^{\circ} \mathrm{C}$, two new phases were observed, a sulphurdeficient $\mathrm{Fe}_{(1-\mathrm{x})} \mathrm{S}$ and an oxygen-enriched $\mathrm{Al}_{2} \mathrm{O}_{3}$ with up to 6 weight \% of sulphur; these are phases 7 and 9 in Figure 9c respectively. Penetration of FeS into the $\mathrm{Al}_{2} \mathrm{O}_{3}$ was not observed at all temperatures.

\section{Discussion}

The effect of temperature on the interactions between FeS and the refractory oxides, $\mathrm{SiO}_{2}$, and $\mathrm{Al}_{2} \mathrm{O}_{3}$ was comparable. At $1200^{\circ} \mathrm{C}$ no new phases were detected, but the $\mathrm{FeS} / \mathrm{SiO}_{2}$ was more prone to cracking than the $\mathrm{FeS} / \mathrm{Al}_{2} \mathrm{O}_{3}$. The phases detected by XRD and SEM-EDS concur. For example, at $1350^{\circ} \mathrm{C}$ and $1500^{\circ} \mathrm{C}$ EDS detected nonstoichiometric $\mathrm{Al}_{2} \mathrm{O}_{3}$ and $\mathrm{SiO}_{2}$ with excess oxygen, while XRD did not detect the oxide peaks at $1350^{\circ} \mathrm{C}$. At $1500^{\circ} \mathrm{C}$, $\mathrm{SiO}_{2}$ was detected, but the $\mathrm{Al}_{2} \mathrm{O}_{3}$ peak was still not detectable. An oxysulphide ( $\mathrm{FeS} / \mathrm{FeO}$ mixture) was detected at $1350^{\circ} \mathrm{C}$ for the $\mathrm{FeS} / \mathrm{Al}_{2} \mathrm{O}_{3}$ specimen and at $1500^{\circ} \mathrm{C}$ for the $\mathrm{FeS} / \mathrm{SiO}_{2}$. A sulphurdeficient iron sulphide $\left(\mathrm{Fe}_{(1-\mathrm{x})} \mathrm{S} / \mathrm{Fe}\right.$ mixture) was detected in the $\mathrm{FeS} / \mathrm{SiO}_{2}$ specimen at $1500^{\circ} \mathrm{C}$.

As shown in the Fe-S phase diagram (Figure 4), sulphur melts at $444.6^{\circ} \mathrm{C}$, while above $450^{\circ} \mathrm{C}$ sulphur is a gas at a pressure of 1 bar (Walder and Pelton, 2005). In the current work, a sulphur-deficient $\mathrm{Fe}-\mathrm{S}$ was observed in the $\mathrm{FeS} / \mathrm{SiO}_{2}$ specimen at $1500^{\circ} \mathrm{C}$ (phase 7 in Figure 9c). This phase could be formed due to vaporization of sulphur at high temperatures. If sulphur is vaporized it would be removed with the off-gas. Upon cooling, the composition of the condensed phases shifted towards the metal-rich end of the Fe-S system in the $\mathrm{Fe}_{(1-\mathrm{x})} \mathrm{S} / \mathrm{Fe}$ phase field.

$\mathrm{Fe}_{(1-\mathrm{x})} \mathrm{S}$ is a solid solution, and the Fe content in $\mathrm{Fe}_{(1-\mathrm{x})} \mathrm{S}$ can vary from 50 atom \% to 46.7 atom \%. A slight change in the Fe:S ratio results in variations in structural, chemical, and other
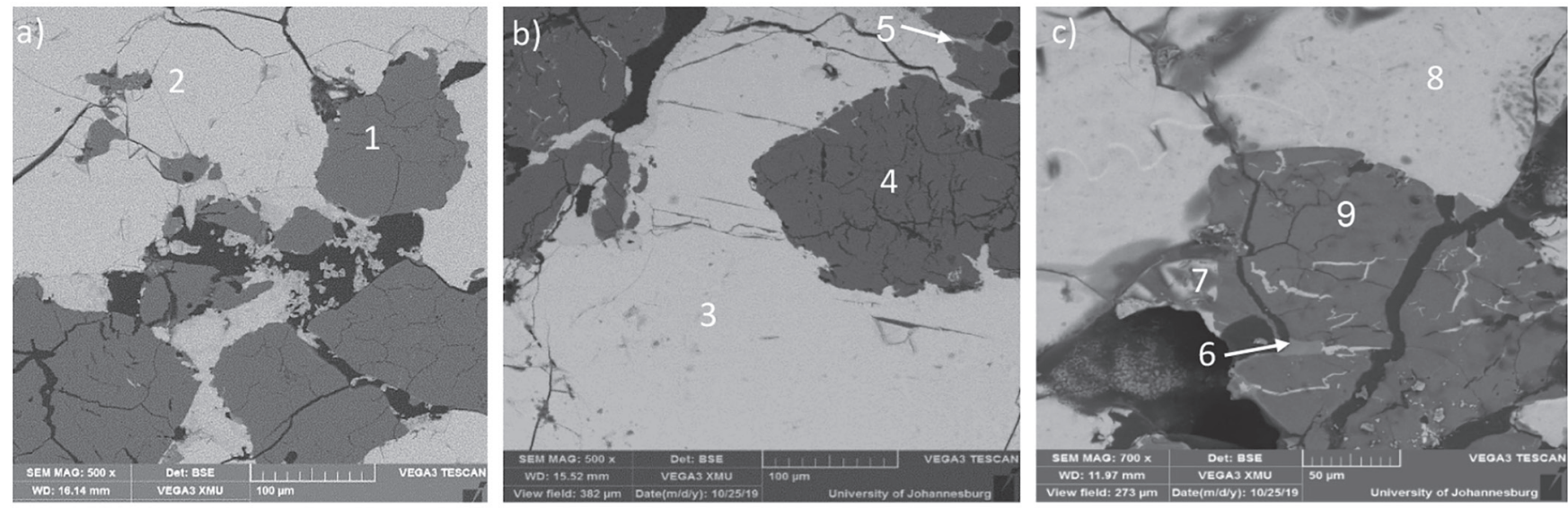

Figure 8-BSE images of the $\mathrm{FeS} / \mathrm{SiO}_{2}$ pellet after exposure at (a) $1200^{\circ} \mathrm{C}$, (b) $1350^{\circ} \mathrm{C}$, and (c) $1500^{\circ} \mathrm{C}$ (refer to the EDS analyses of the annotated phases in Table II)

\begin{tabular}{|c|c|c|c|c|c|c|c|c|c|}
\hline \multicolumn{10}{|c|}{$\begin{array}{l}\text { EDS analysis of the } \mathrm{FeS} / \mathrm{SiO}_{2} \text { couple after exposure at } 1200^{\circ} \mathrm{C}, 1350^{\circ} \mathrm{C} \text {, and } 1500^{\circ} \mathrm{C} \text { (refer to the } \mathrm{BSE} \text { images in Figure } 8 \text { ) } \\
\text { (weight \%) }\end{array}$} \\
\hline Element & 1 & 2 & 3 & 4 & 5 & 6 & 7 & 8 & 9 \\
\hline 0 & 62.4 & - & - & 55.4 & 70.3 & 76.4 & 66.1 & 11.7 & 69.2 \\
\hline $\mathrm{Fe}$ & 0.2 & 45.3 & 40.3 & 2.3 & - & 0.9 & 2.4 & 31 & 0.1 \\
\hline$S$ & - & 54.7 & 59.7 & 2.9 & - & 0.4 & 12.4 & 57.3 & - \\
\hline $\mathrm{Si}$ & 37.4 & - & - & 39.4 & 29.7 & 22.3 & 19.1 & - & 30.7 \\
\hline Phase composition & $\mathrm{SiO}_{3}$ & $\mathrm{Fe}_{(1-x)} \mathrm{S}+\mathrm{FeS}_{2}$ & $\mathrm{Fe}_{(1-x)} \mathrm{S}+\mathrm{FeS}_{2}$ & $\mathrm{SiO}_{2}$ & $\mathrm{SiO}_{4}$ & $\mathrm{SiO}_{4}$ & Sis-O & $\mathrm{FeS}+\mathrm{FeO}$ & $\mathrm{SiO}_{4}$ \\
\hline
\end{tabular}




\section{On the interactions of iron sulphide with alumina and silica}
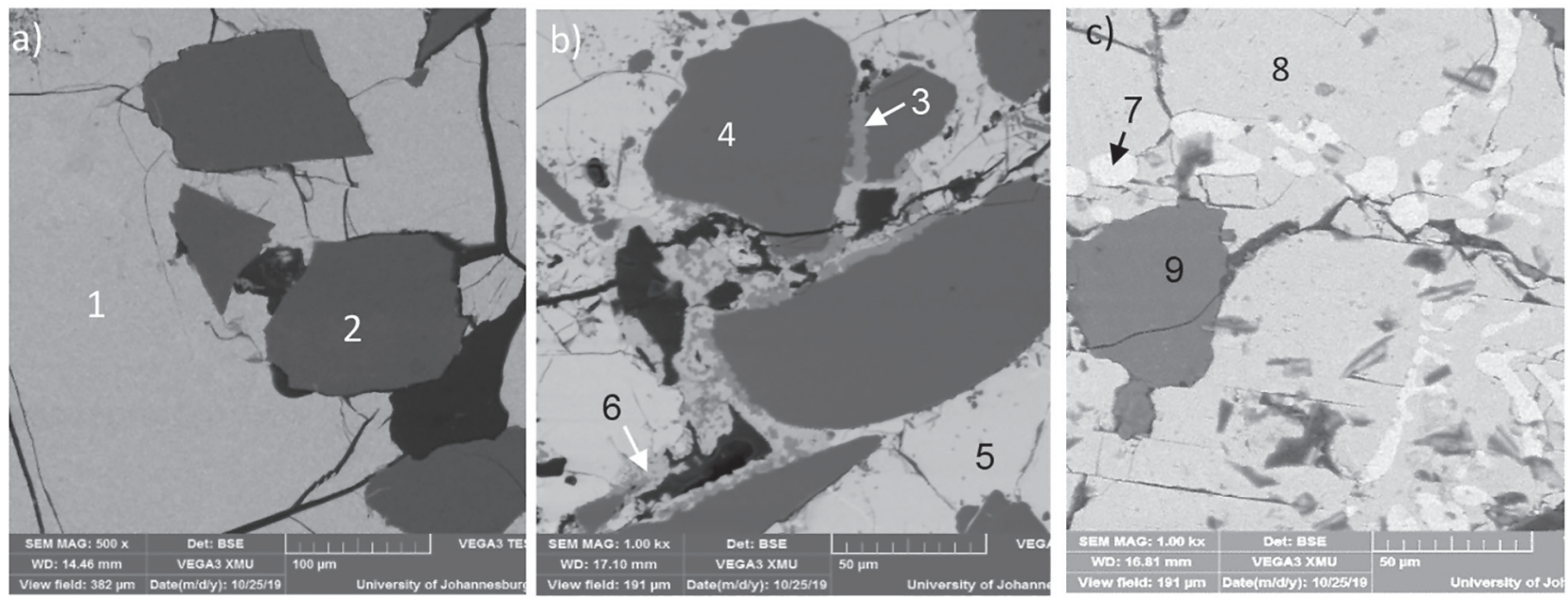

Figure 9-BSE images of the $\mathrm{Al}_{2} \mathrm{O}_{3}$ pellet after exposure at (a) $1200^{\circ} \mathrm{C}$, (b) $1350^{\circ} \mathrm{C}$, and (c) $1500^{\circ} \mathrm{C}$. The EDS analyses of the annotated phases are in Table III

\section{Table III}

EDS analyses of the $\mathrm{FeS}-\mathrm{Al}_{2} \mathrm{O}_{3}$ couple after exposure at $120^{\circ} \mathrm{C}, 1350^{\circ} \mathrm{C}$, and $1500^{\circ} \mathrm{C}$ (BSE images in Figure 9) (weight \%)

\begin{tabular}{|l|c|c|c|c|c|c|c|c|c|}
\hline Element & $\mathbf{1}$ & $\mathbf{2}$ & $\mathbf{3}$ & $\mathbf{4}$ & $\mathbf{5}$ & $\mathbf{6}$ & $\mathbf{7}$ & $\mathbf{8}$ & $\mathbf{9}$ \\
\hline $\mathrm{O}-$ & 50.9 & 67.5 & 53.1 & - & 35.5 & - & - & 74 \\
$\mathrm{Al}-$ & 48.5 & 32.5 & 43.6 & - & - & - & - & 19.7 \\
$\mathrm{Fe} 55.3$ & 0.6 & - & 0.2 & 44.8 & 55.3 & 77.5 & 49 & - \\
$\mathrm{S} 44.7$ & - & - & 3.1 & 55.2 & 9.2 & 22.6 & 51 & 6.3 \\
Phase composition & $\mathrm{Fe}_{(1-1)} \mathrm{S}+\mathrm{FeS}_{2}$ & $\mathrm{Al}_{2} \mathrm{O}_{3}$ & $\mathrm{Al}_{2} \mathrm{O}_{3}$ & $\mathrm{Al}_{2} \mathrm{O}_{3}$ & $\left.\mathrm{Fe}_{(1-\times)}\right) \mathrm{S}+\mathrm{FeS}_{2}$ & $\mathrm{FeS}+\mathrm{FeO}$ & $\mathrm{Fe}_{(1-\times)} \mathrm{S}+\mathrm{Fe}$ & $\mathrm{Fe}_{(1-\times)} \mathrm{S}+\mathrm{FeS}_{2}$ & $\mathrm{Al}_{2} \mathrm{O}_{3}$ \\
\hline
\end{tabular}

physical properties of $\mathrm{Fe}_{(1-\mathrm{x})} \mathrm{S}$. The polymorphs are FeS (troilite) and $\mathrm{Fe}_{(1-\mathrm{x})} \mathrm{S}$ (pyrrhotite). Pyrrhotite is Fe-deficient and is stable at various Fe to $\mathrm{S}$ ratios; $\mathrm{Fe} 8 \mathrm{~S}_{9}, \mathrm{Fe}_{9} \mathrm{~S}_{10}, \mathrm{Fe}_{10} \mathrm{~S}_{11}$, and $\mathrm{Fe}_{11} \mathrm{~S}_{12}$ (Li, 1997; Roberts et al., 2018). These polymorphs present different diffraction patterns because the temperature of formation and the cooling/heating rate determine the final diffraction pattern (Roberts et al., 2018). The FeS phase relations display extensive solid solution and several polymorphs, as discussed above. These attributes posed a challenge in explaining nonstoichiometric phases.

$\mathrm{Al}_{2} \mathrm{O}_{3}$ and $\mathrm{SiO}_{2}$ are the only condensed oxide phases of $\mathrm{Al}$ and $\mathrm{Si}$ respectively (Haiste, 1978). This implies that the analyses of the nonstoichiometric oxide phases reported at $1350^{\circ} \mathrm{C}$ and $1500^{\circ} \mathrm{C}$ are not accurate. To improve these analyses a technique such as the electron microprobe might be more suited for determining the accurate stoichiometry of oxygen in the oxide phases.

Tridymite and cristobalite are polymorphs of $\mathrm{SiO}_{2}$; tridymite is stable between $867^{\circ} \mathrm{C}$ and $1470^{\circ} \mathrm{C}$, while cristobalite is stable from $1470^{\circ} \mathrm{C}$ to the melting temperature. The volatile species in the $\mathrm{Si}-\mathrm{O}$ system include $\mathrm{Si}(\mathrm{g}), \mathrm{Si}_{2}(\mathrm{~g}), \mathrm{Si}_{3}(\mathrm{~g}), \mathrm{SiO}(\mathrm{g})$, and $\mathrm{SiO}_{2}(g)$ (Haiste 1978).

In the Si-O-S system, the condensed phases are $\mathrm{SiS}(\mathrm{s}, \mathrm{l})$ and $\mathrm{SiS}_{2}$ (s,l); these sulphides melt at $1090^{\circ} \mathrm{C}$, while solid $\mathrm{SiS}_{2}$ forms in high-sulphur environments. SiS and $\mathrm{SiS}_{2}$ are volatile, and this can lead to depletion of silicon in a system (Haiste, 1978). $\mathrm{SiS}_{2}$ has been detected in a gas condensate after exposure of a typical PGM matte to a graphite crucible at temperatures up to $1450^{\circ} \mathrm{C}$. Such $\mathrm{SiS}_{2}$ formation was a result of sulphides interacting with oxide inclusions in matte, although the mechanism of formation was not investigated (Thethwayo and Cromarty, 2015).
In the FeO-FeS-SiO ${ }_{2}$ system, the FeS can react with $\mathrm{SiO}_{2}$ according to Equation [1] (Jo, Lee, and Kang, 2013). FeS can be oxidized to $\mathrm{FeO}$ and sulphur gas according to Equation [2] (Chen et al., 2020).

$$
\begin{aligned}
& \mathrm{FeS}(l)+\mathrm{SiO}_{2}(l)=\mathrm{FeO}(l)+\mathrm{SiS}_{2} 1400{ }^{\circ} \mathrm{C}[1] \\
& \mathrm{FeS}(l)+0.5 \mathrm{O}_{2}(l)=\mathrm{FeO}(l)+0.5 S_{2}(g)
\end{aligned}
$$

The products in the $\mathrm{FeS} / \mathrm{SiO}_{2}$ specimen comprised an $\mathrm{FeS} /$ $\mathrm{FeO}$ mixture and a phase with $\mathrm{Si}-\mathrm{O}-\mathrm{S}$ (phases 7 and 8 in Figure $8 \mathrm{c})$. The formation of these phases can be explained by the reactions in Equations [1] and [2]. From the discussion above, it is apparent that $\mathrm{SiS}_{2}$ melts at $1090^{\circ} \mathrm{C}$ and is highly volatile, therefore any $\mathrm{SiS}_{2}$ formed would vaporize, leading to losses of $\mathrm{Si}$ and $\mathrm{S}$ in the residual melt. The vaporization of $\mathrm{SiS}_{2}$ would also result in the formation of a nonstoichiometric oxide with excess oxygen, as observed at $1350^{\circ} \mathrm{C}$ and $1500^{\circ} \mathrm{C}$. The off-gas stream was not analysed in the current work, but the vaporization of $\mathrm{Si}$ and $S$ is a plausible mechanism that can lead to the loss of Si and $\mathrm{S}$, resulting in sulphur-deficient residual sulphides.

An oxidized silicon sulphide has been reported by Li et al. (2019). SiS can accommodate from 0.1 to 1 atoms of oxygen in its structure (Li et al., 2019). The formation of the SiS-O phase (phase 7 in Figure 8c) can thus be attributed to the dissolution of oxygen within the SiS (Li et al., 2019).

$\mathrm{FeS}$ and $\mathrm{FeO}$ form a complete solid solution according to the phase diagram in Figure 10 (McLennan et al., 2000). If the FeO formed according to Equations [1] and [2], it would dissolve in the FeS, thus forming a solid solution.

In the Al-O-S system, the condensed phases are $\mathrm{Al}_{2} \mathrm{O}_{3}, \mathrm{AlS}$, and $\mathrm{Al}_{2} \mathrm{~S}_{3} . \mathrm{Al}_{2} \mathrm{~S}_{3}$ is the most stable sulphide at room temperature, 


\section{On the interactions of iron sulphide with alumina and silica}

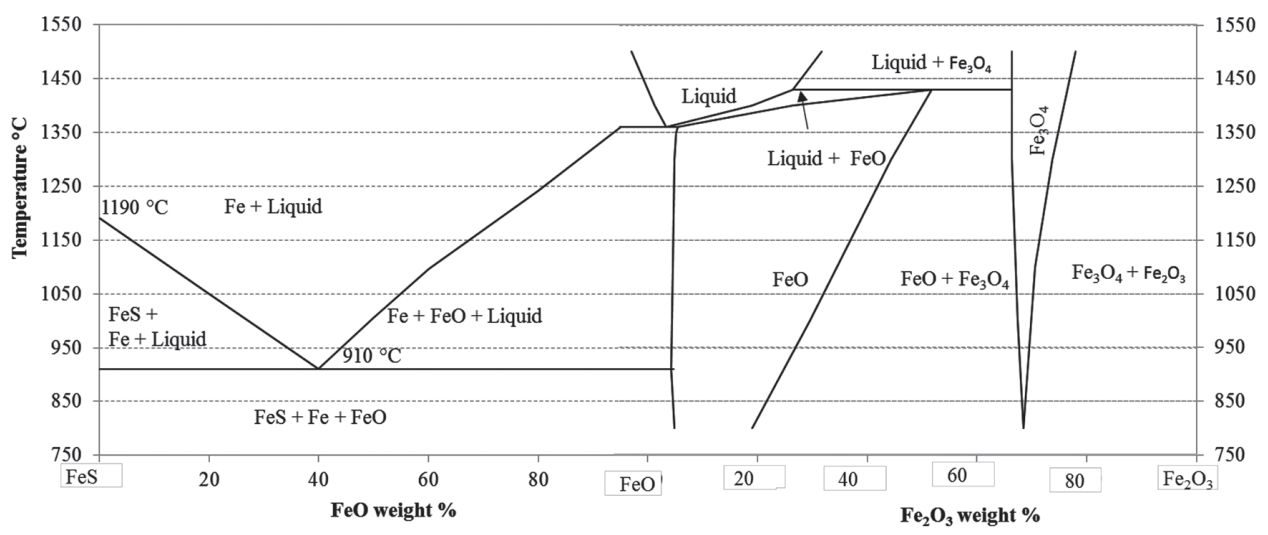

Figure $10-\mathrm{FeS}-\mathrm{FeO}-\mathrm{Fe}_{2} \mathrm{O}_{3}$ equilibrium phase diagram vs. temperature (McLennan et al., 2000)

while AlS melts at $1197^{\circ} \mathrm{C}$, and $\mathrm{Al}_{2} \mathrm{~S}_{3}$ melts at $1097^{\circ} \mathrm{C}$. The volatile species include $\mathrm{Al}, \mathrm{AlS}, \mathrm{Al}_{2} \mathrm{~S}$, and $\mathrm{Al}_{2} \mathrm{~S}_{2}$ (Haiste 1978). According to Huda et al. (2013), $\mathrm{Al}_{2} \mathrm{~S}_{3}$ can form by the reaction of $\mathrm{Al}_{2} \mathrm{O}_{3}$ with any sulphur source in the presence of a reductant. Upon heating, $\mathrm{Al}_{2} \mathrm{~S}_{3}$ can be converted to AlS and sulphur (Huda et al., 2016). Although the graphite crucible was used to house the specimen, an alumina plate was used to separate the specimen from the graphite. The prevailing environment inside the specimen was assumed to be slightly oxidizing, considering the formation of an oxysulphide. The mechanism responsible for the formation of the oxysulphide and the nonstoichiometric $\mathrm{Al}_{2} \mathrm{O}_{3}$ remains a mystery. Future work will focus on studying this system in depth using more controlled environments.

The sulphur-deficient FeS could form as per the reaction in Equation [2].

\section{Conclusions}

The postulation was tested that refractory brick components may individually be reactive towards matte species. Temperature was found to have a significant effect on the reactivity between FeS and the tested oxides. At $1200^{\circ} \mathrm{C}$ there was no evidence of interaction apart from minor cracks in the $\mathrm{FeS} / \mathrm{SiO}_{2}$ specimen. At $1350^{\circ} \mathrm{C}$ an intermediate phase was observed at the boundary of the oxide grain, and penetration of $\mathrm{FeS}$ into $\mathrm{SiO}_{2}$ was enhanced. The penetration of FeS through $\mathrm{SiO}_{2}$ was noticeably more prominent at $1500^{\circ} \mathrm{C}$, with the formation of oxidized SiS and an iron oxysulphide. $\mathrm{Al}_{2} \mathrm{O}_{3}$ was less reactive than $\mathrm{SiO}_{2}$, and the detection of nonstoichiometric oxides and the scarcity of data on the FeS- $\mathrm{Al}_{2} \mathrm{O}_{3}$ system made it a challenge to study the mechanism of $\mathrm{FeS} / \mathrm{Al}_{2} \mathrm{O}_{3}$ interaction. It is therefore concluded that, for the tested conditions, the oxide components of a refractory brick can react with the components of the matte such as FeS

\section{References}

Chen, M., Avarmaa, K., Klemettinen, L., Shi, J., Taskinen, P., and Jokilaakso, A. 2020. Experimental study on the phase equilibrium of copper matte and silicasaturated $\mathrm{FeO}_{\mathrm{x}} \mathrm{SiO}_{2}$ based slags in pyrometallurgical WEEE processing, Metallurgical and Materials Transactions B. https://doi.org/10.1007/s11663020-01874-0

Du Toit, J., Cromarty, R.D., and Garbers-Craig, A.M. 2016. Matte-tap-hole clay refractory brick interaction in a PGM smelter. Journal of the Southern African Institute of Mining and Metallurgy, vol. 116, no. 4. pp. 339-342.

EKSTEEN, J. 2011. A mechanistic model to predict matte temperatures during the smelting of UG2 rich blends of platinum group metal concentrates. Minerals Engineering, vol. 24. pp. 676-687.
HASTIE, J.W. 1978. Characterization of high temperature vapors and gases: Proceedings of the 10th Materials Research Symposium, National Bureau of Standards, Gaithersburg, MD, 18-22 September 1978, 1. pp. 1642-1655.

Huda, N., Rhamdhani, M.A., Brooks, G.A., Monaghan, B.J., and Prentice, L. 2016. Production of aluminum sulfide through carbosulfidation utilising $\mathrm{H}_{2} \mathrm{~S}$. Proceedings of Light Metals 2013. Sadler, B. (ed.). Springer. pp. 1299-1304. https://doi.org/10.1007

Hundermark, R., Mncwango, S., de Villiers, L., and Nelson, L. 2011. The smelting operations of Anglo American's platinum business: an update. Proceedings of Southern African Pyrometallurgy, Cradle of Humankind, South Africa, 6-9 March 2011. Jones, R. and den Hoed, P. (eds.). Southern African Institute of Mining and Metallurgy, Johannesburg. pp. 295-308.

Jo, Y., LeE, H.G., and Kang, Y.B. 2013. Thermodynamics of the MnO-FeO-MnS-FeS$\mathrm{SiO}_{2}$ system at $\mathrm{SiO}_{2}$ saturation under reducing condition: Immiscibility in the liquid phase. Iron and Steel Institute of Japan International, vol. 53, no. 5. pp. 751-760.

LI, F. 1997. Studies of structures and phase transitions in pyrrhotite (No. IS-T1774). PhD dissertation, Ames Laboratory, Iowa State University. pp. 2.

Li, Z., Song, S., Dong, S., and GuAn, J. 2019. Oxidized silicon sulfide: stability and electronic properties of a novel two-dimensional material. Journal of Physical Chemistry C, vol. 123, no. 49. pp. 29986-29993.

Mclennan, A.R., Bryant, G.W., Bailey, C.W., Stanmore, B.R., and Wall, T.F. 2000. Index for iron based slagging for pulverized coal firing in oxidizing and reducing conditions. Energy and Fuels, vol. 14. pp. 349-354.

Ramakobya, T., Thethwayo, B.M., and Mulaba-Bafubiandi, A.F. 2019. The interaction of refractory oxide with matte. Proceedings of the 17th International Conference on Science, Engineering, Technology \& Waste Management (SETWM-19), Johannesburg, South Africa, 18-19 November 2019. North West University, Potchefstroom, South Africa. pp. 15-17.

RoberTs, D.M., Landin, A.R., RitTer, T.G., EAves, J.D., and Stoldt, C.R. 2018. Nanocrystalline iron monosulfides near stoichiometry. Scientific Reports, vol. 8, no. 1. pp.1-10.

Tesfaye, F. and TAskinen, P. 2010. Sulfide Mineralogy-Literature Review. Aalto University Publications in Materials Science and Engineering, Espoo, Finland. TKK-MT-214, pp. 26-28.

Thethwayo, B.M. and Garbers-Craig, A.M. 2014. Wear of graphite and micropore carbon by synthetic PGM matte. Proceedings of the Unified International Technical Conference on Refractories (UNITECR 2013). Goski, D.G. and Smith, J.D. (eds.). Wiley. pp. 1067-1074.

THETHWAYo, B.M. and CROMARTY, R.D. 2015. Compatibility of graphite with primary platinum group metals industrial matte. Materials Research Innovations, vol. 19 (sup5). pp. S5-948.

Thethwayo B.M. 2019. Interaction of carbon-based refractories with liquid PGMfurnace melt. PhD thesis, University of Pretoria, South Africa.

Walder, P. and Pelton, A.D. 2005. Thermodynamic modeling of the Fe-S system. Journal of Phase Equilibria and Diffusion, vol. 26, no. 1. pp. 23-38. 